ТЕОРЕТИЧНІ ПРОБЛЕМИ РОЗВИТКУ НАЦІОНАЛЬНОЇ ЕКОНОМІКИ

УДК 502/504

DOI: $10.25140 / 2411-5215-2021-2(26)-7-17$

Ірина Кичко, Алла Холодницька

\title{
РАЦІОНАЛЬНЕ ВОДОКОРИСТУВАННЯ В КОНТЕКСТІ ЗАБЕЗПЕЧЕННЯ НАСЕЛЕННЯ ЯКІСНОЮ ПИТНОЮ ВОДОЮ, ЗБЕРЕЖЕННЯ ЗДОРОВ'Я ТА ТРИВАЛОСТІ ЖИТТЯ
}

\author{
Iryna Kychko, Alla Kholodnytska
}

\section{RATIONAL WATER STORAGE IN THE CONTEXT OF SAFETY OF THE POPULATION WITH DRINKING WATER, PROTECTION OF HEALTH AND TRIVIALITY OF LIFE}

\begin{abstract}
У статті обтрунтовано, що якість водних ресурсів є одним із вагомих чинників тривалості життя. Систематизовано джерела забруднення водних ресурсів Украӥни, розглянуто категорії стічних вод у розрізі ступеня їх очищення. Обтрунтовано за допомогою емпіричних, статистичних методів, а також порівняння, систематизації та узагальнення вплив рівня забруднення водних ресурсів на демографічні процеси та розроблено коригуючі заходи водокористування щуодо запобігання погіршення якості води, негативних наслідків спожсивання населенням водних ресурсів. Визначено, щуо для покращення екологічних показників водних ресурсів Украӥни необхідно вирішити такі завдання, як зменшити рівень забруднення стічних вод шляхом реконструкиії і ремонту каналізаиійних мереж $і$ споруд та використання сучасних технологій очистки води; сприяти на державному рівні формуванню екологічних потреб, щчо може суттєво зменшити рівень забруднення; створювати програми стимулювання соиіальної відповідальності бізнесу за допомогою фінансових, адміністративних важелів.

Ключові слова: водні ресурси; якість води; тривалість життя; трудовий потенціал; екологічні потреби; раціональне водокористування; сочіальна відповідальність бізнесу.

Рис.: 7. Табл.: 3. Бібл.: 20.

Within the article it is substantiated that the quality of water resources is one of the important factors of life expectancy. Sources of the water resources pollution in Ukraine are systematized, categories of wastewater in terms of the degree of their treatment are considered. Using empirical, statistical methods, the influence of the water pollution level on demographic processes is substantiated; and corrective measures for the water use to prevent deterioration of the water quality, negative consequences of public consumption of water resources by population are developed. It is determined that in order to improve ecological indicators of water resources of Ukraine it is necessary to solve such tasks as: to reduce the level of wastewater pollution by reconstruction and repair of sewerage networks and structures and to use modern water treatment technologies; to promote the formation of environmental needs at the state level, which can significantly reduce the level of pollution; to create programs to stimulate social responsibility of business with the help of financial, administrative levers.

Keywords: water resources; water quality; lifetime; labor potential; environmental needs; rational water use; social responsibility of business.

Fig.: 7. Table: 3. References: 20
\end{abstract}

JEL Classification: Q20; Q25

Постановка проблеми. Активізація міграційних процесів, підвищення рівня смертності в Україні дедалі гостріше проявляє проблему збереження трудового потенціалу, збалансування ринку праці, де вже відчувається брак робочої сили різної кваліфікації [6; 17]. При систематизації факторів впливу на тривалість життя населення поряд із генетичними чинниками, способом життя більшої ваги набувають екологічні чинники - рівень забруднення атмосферного повітря, землі, водних ресурсів. Стічні води комунальних та промислових підприємств потрапляють у грунт, водойми. Опади у вигляді дощу і снігу випадають разом з атмосферними забрудненнями і потрапляють у грунтові води. Шкідливі речовини тоннами опиняються у воді, забруднюючи навколишнє середовище.

Водопостачання численних міст, сіл та селищ повністю залежить від річок, наявності води в колодязях. Позбавлення ж води від органічних і мінеральних домішок стає все важчою і дорожчою, вода ж у колодязях зникає взагалі. Через ці обставини ризик погіршення здоров'я населення підвищується. Наслідки знаходження у воді деяких речовин, повне видалення яких не може забезпечити ні одна система очищення стічних вод, можуть з часом позначитися на здоров'ї населення, тривалості його життя, здатності до відтворення.

() Кичко І. І., Холодницька А. В., 2021 
У сучасному світі антропогенний вплив на здоров'я людини стає глобальною проблемою, що вимагає прийняття термінових, кардинальних заходів. 3 підвищенням техногенного тиску на навколишнє середовище, якість водних ресурсів неухильно знижується, що, безумовно, підвищує актуальність дослідження питання якості, доступності водних ресурсів, пошуків шляхів раціонального водокористування.

Аналіз останніх досліджень і публікацій. Теоретичну та методологічну основу дослідження становлять праці науковців, які досліджують: Н. Авраменко, О. Климчик, Л. Левковська [10], В. Мандзик [12], Є. Мішенін [13], Т. Пінкіна, А. Пінкін, А. Сундук еколого-економічні питання раціонального водокористування; Ж. Дерій [2; 3], О. Лотоцька, В. Кондратюк, С. Кучер, С. Мовчан - вплив рівня забруднення водних ресурсів на здоров'я населення.

Виділення недосліджених частин загальної проблеми. Незважаючи на детальне вивчення науковцями складових проблеми впливу якості водних ресурсів на тривалість та якість життя населення, потребує уточнення еколого-економічний підхід до раціонального водокористування, збереження водних ресурсів та забезпечення потреб населення у якісній питній воді.

Мета статті $\epsilon$ обгрунтування впливу рівня забруднення водних ресурсів на здоров'я та тривалість життя у контексті раціонального водокористування, реалізації соціальної відповідальності бізнесу та екологічних потреб населення України.

Виклад основного матеріалу. Доведено, що якість питної води істотно впливає на здійснення фізіологічних та біохімічних процесів в організмі людини, а отже, на стан ії здоров'я та можливість повноцінно використовувати власний трудовий потенціал.

Людське тіло більш ніж наполовину складається з води, яка впливає на біохімічні процеси організму. Ми не тільки вживаємо воду в чистому вигляді, також отримуємо іiі разом з їжею, вдихаємо водяні пари. Але, на жаль, якість споживаної води щорічно стає все гіршою. Водопровідна вода, вода зі свердловини не відповідає санітарним нормам, хоча якість підземних вод вища, ніж у відкритих водоймах. Підземні води проходять через пісок, глину, каміння, як через систему фільтрів. Але таке очищення не видаляє всі шкідливі речовини.

Глобальні дослідження науковців Великої Британії, Нідерландів, США у 2019 році в Україні зафіксували найнижчий серед європейських країн показник здорового життя. У дослідженні ключовим показником є роки життя 3 поправкою на інвалідність. Його особливістю $\epsilon$ те, що він визначає не лише середню тривалість життя, а і враховує вплив на неї хвороб. Це дозволяє зробити коригування на кількість років, втрачених через захворюваність, інвалідність чи смертність (втрачені роки здорового життя) (рис. 1).

1. Словенія $(70,1)$

3. Чехія $(68,5)$

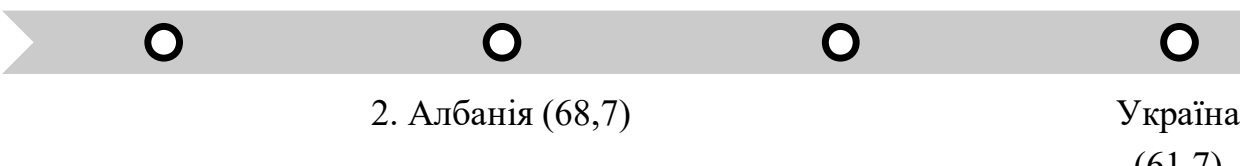

$(61,7)$

Рис. 1. Значення показника тривалості здорового життя в країнах Свропи у 2019 рочฺ Джерело: [19].

Цей показник є значно нижчим за середню тривалість життя в країнах, який не враховує втрату років через погане здоров'я. Так, тривалість життя в Україні в середньому становить 72,01 року, що за DALY більше приблизно на 10 років [18].

На рис. 2 розглянемо показник очікуваної тривалості життя без врахування втрачених років здорового життя. 
ТЕОРЕТИЧНІ ПРОБЛЕМИ РОЗВИТКУ НАЦІОНАЛЬНОЇ ЕКОНОМІКИ

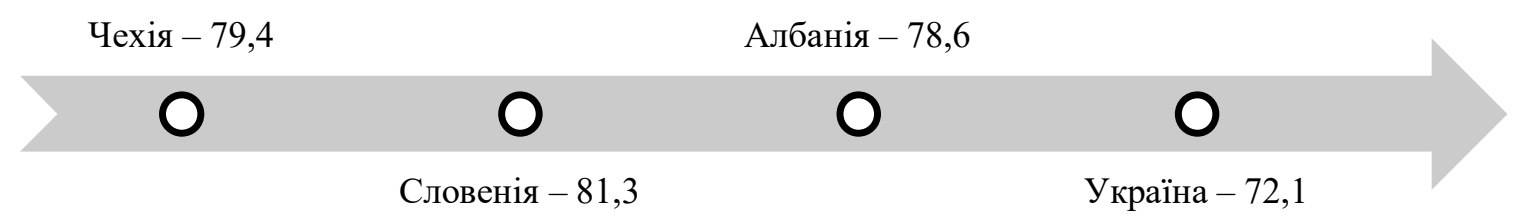

Рис. 2. Очікувана тривалість життя при народженні у 2019 рочуі Джерело: [20].

Як бачимо, різниця є відчутною, оскільки через повний стан здоров'я очікувана тривалість життя помітно скорочується й у розрізі країн, що обрані для дослідження, вона становить відповідно: у Словенії - 11,2 року, у Чехії - 10,9 року, в Албанії 9,9 року, в Україні - 10,4 року. Причиною такої ситуації $є$ високий рівень захворюваності, значний відсоток людей з інвалідністю та важкими захворюваннями, причиною яких у тому числі $є$ і проблеми забезпечення населення якісною питною водою.

У світових рейтингах очікуваної тривалості життя Україна посідає 113-є місце серед 189 країн, що були досліджені. У трійці лідерів Гонконг, Японія та Швейцарія (табл. 1).

Таблиця 1

Місие Украӥни у світових рейтингах за показником очікуваної тривалості життя при народженні у 2019 роиі

\begin{tabular}{|l|c|c|}
\hline \multicolumn{1}{|c|}{ Країна } & Очікувана тривалість життя при народженні & Місце у світовому рейтингу \\
\hline Гонконг & 85,0 & 1 \\
\hline Японія & 84,8 & 2 \\
\hline Швейцарія & 83,8 & 3 \\
\hline Сінгапур & 83,6 & 4 \\
\hline Іспанія & 83,6 & 5 \\
\hline Словенія & 81,3 & 28 \\
\hline Чехія & 79,4 & 35 \\
\hline Україна & $\mathbf{7 2 , 1}$ & $\mathbf{1 1 3}$ \\
\hline
\end{tabular}

Джерело: [20].

Низькі позиції України у рейтингу за очікуваною тривалістю життя порівняно з розвинутими країнами світу частково зумовлені й неналежною якістю питної води, яка $є$ одним із факторів впливу на стан здоров'я населення.

Чернігівська область, порівняно з іншими регіонами України, достатньою мірою забезпечена запасами водних ресурсів.

Основним джерелом забезпечення потреб населення, а також промислових та сільськогосподарських підприємств є підземні води питної якості.

Втім, останнім часом спостерігається поступове підвищення вмісту біогенних елементів, яке призводить до евтрофікації вод. У результаті відбувається зменшення видового різноманіття та погіршення якості питної води. Неналежний стан очисних споруд, що спричиняє неповноцінну їхню роботу, здійснює негативний вплив на гідрохімічний стан річок. Найвище навантаження зафіксоване в басейнах річок Білоус, Вздвиж, Іченька, Борзенка, Остер, Удай та Снов. Причиною цьому є застаріле обладнання очисних споруд, їх перезавантаження, зношене обладнання каналізаційних мереж, відсутність повноцінних капітальних та поточних ремонтів. 
ТЕОРЕТИЧНІ ПРОБЛЕМИ РОЗВИТКУ НАЦІОНАЛЬНОЇ ЕКОНОМІКИ

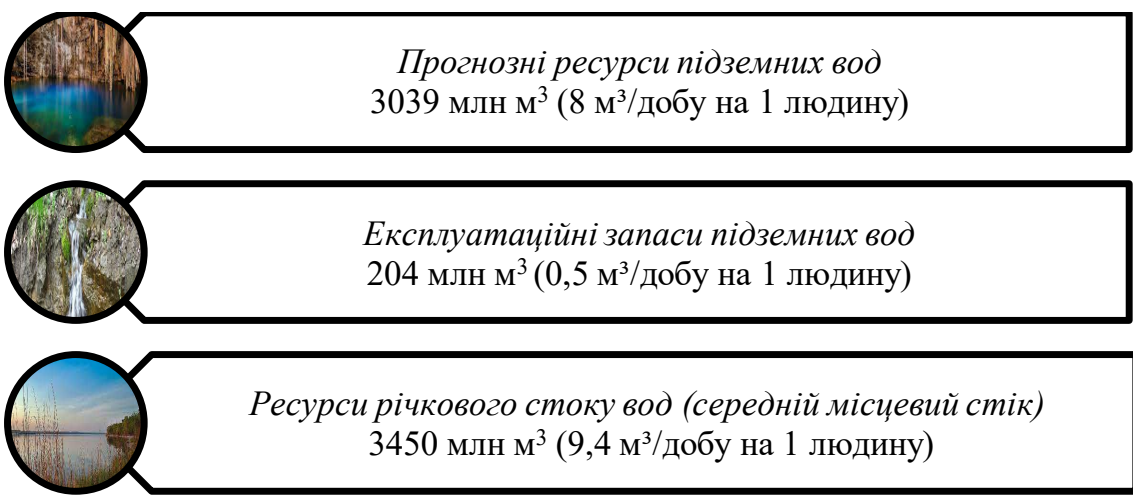

Рис. 3. Прогнозні ресурси підземних вод, їх експлуатаційні запаси

Джерело: [5].

та ресурси річкового стоку Чернігівської області у 2020 році

У 2020 році населення та галузі економіки Чернігівщини були забезпечені питною та технічною водою в достатньому обсязі. Дані щодо використання водних ресурсів наведено в таблиці 2.

Таблиця 2

Використання водних ресурсів у Чернігівській області у 2019-2020 ройі, млн м

\begin{tabular}{|c|c|c|c|}
\hline Показники & 2019 & 2020 & Абсолютне відхилення $(+;-)$ \\
\hline Загальний обсяг забору води & 101,5 & 107,0 & $+5,5$ \\
\hline Ут. ч. підземної & 43,8 & 42,0 & $-1,8$ \\
\hline поверхневої & 57,7 & 65,0 & $+7,3$ \\
\hline
\end{tabular}

Джерело: [5].

Порівняно з 2019 роком забір підземної води скоротився на 1,8 млн м³ , натомість поверхневої води навпаки збільшився на 7,3 млн м ${ }^{3}$. Використання водних ресурсів у розрізі потреб наведемо на рис. 4.

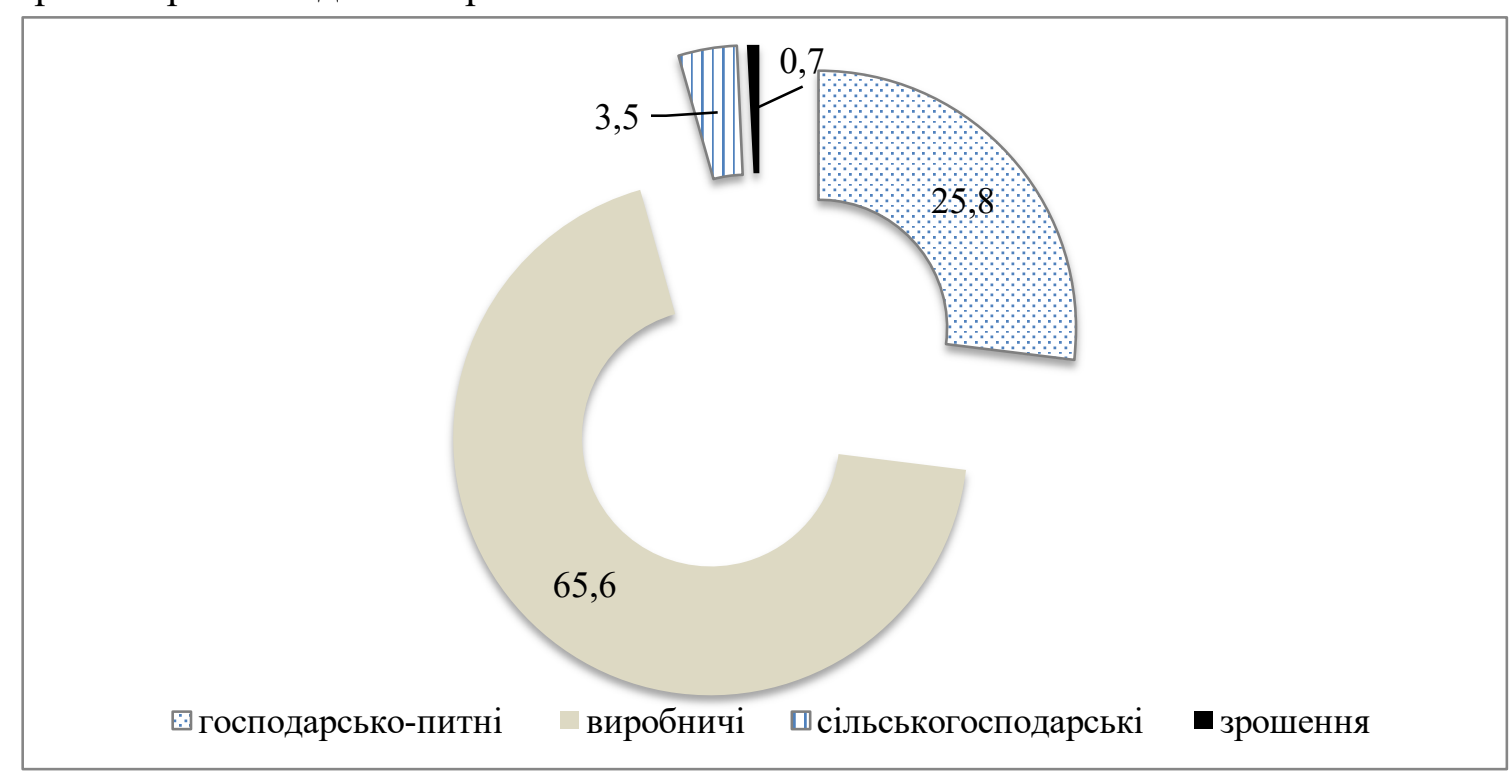

Рис. 4. Обсяги використання водних ресурсів у розрізі потреб

Джерело: [5].

$$
\text { у Чернігівській області у } 2020 \text { рочі, млн } \text { м }^{3}
$$

Як бачимо, найбільша кількість води використовується для виробничих та господарсько-питних потреб, що становить 65,6 та 25,8 млн м³ відповідно.

Найбільшим користувачем підземних вод $є$ Комунальне підприємство «Чернігівводоканал» (м. Чернігів). 
ТЕОРЕТИЧНІ ПРОБЛЕМИ РОЗВИТКУ НАЦІОНАЛЬНОЇ ЕКОНОМІКИ

За 2020 рік у поверхневі води Чернігівської області скинуто 67,6 млн м³ зворотних (стічних) вод, які надходили із 27 точкових джерел забруднення.

На рис. 5 зображено об'єм скинутих стічних вод у поверхневі водні об'єкти в розрізі галузей економіки.

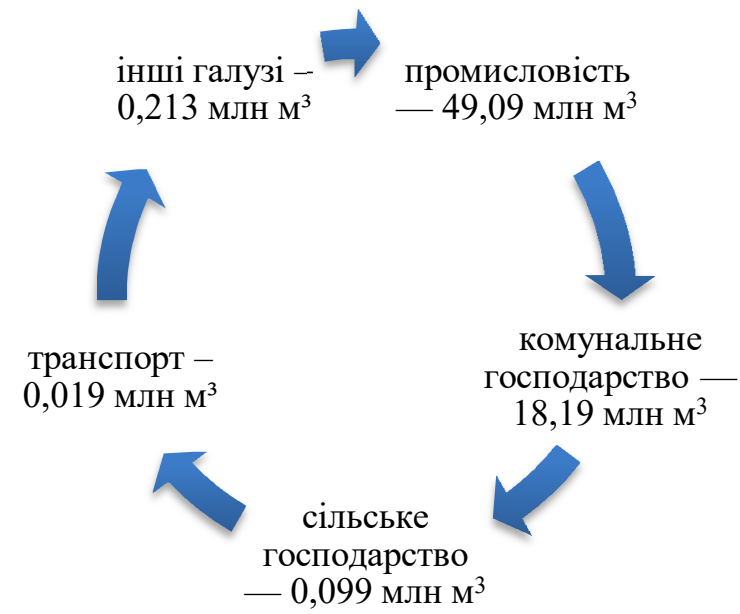

Рис. 5. Об'єм скинутих стічних вод у поверхневі водні об'єкти Чернігівської області

Джерело: [5].

$$
\text { у розрізі за галузей економіки за даними } 2020 \text { року }
$$

Промисловість області найбільше скидає стічних вод у водні об’єкти - 49,09 млн м³ , а також значні обсяги припадають на підприємства комунального господарства 18,19 млн м². Обсяги скинутих стічних вод від сільського господарства, транспорту та інших галузей незначні та становлять 0,099 млн м³ 0,019 млн м³ та 0,213 млн м відповідно.

Основні джерела забруднення водних ресурсів систематизуємо на рис. 6.

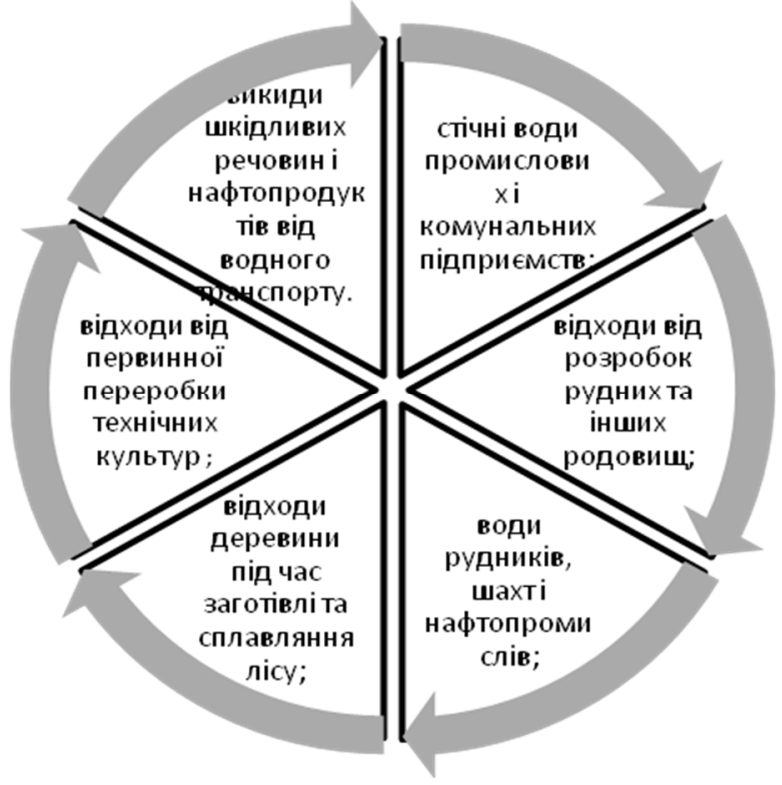

Рис. 6. Основні джерела забруднення водних ресурсів

Джерело: систематизовано авторами за [4].

Приведені статистичні показники підтверджують той факт, що якість води , яка споживається населенням, значною мірою залежить від ступеня очищення стічних вод.

Стічні води прийнято поділяти на три категорії (нормативно чисті, нормативно очищені та забруднені) (рис. 7). 


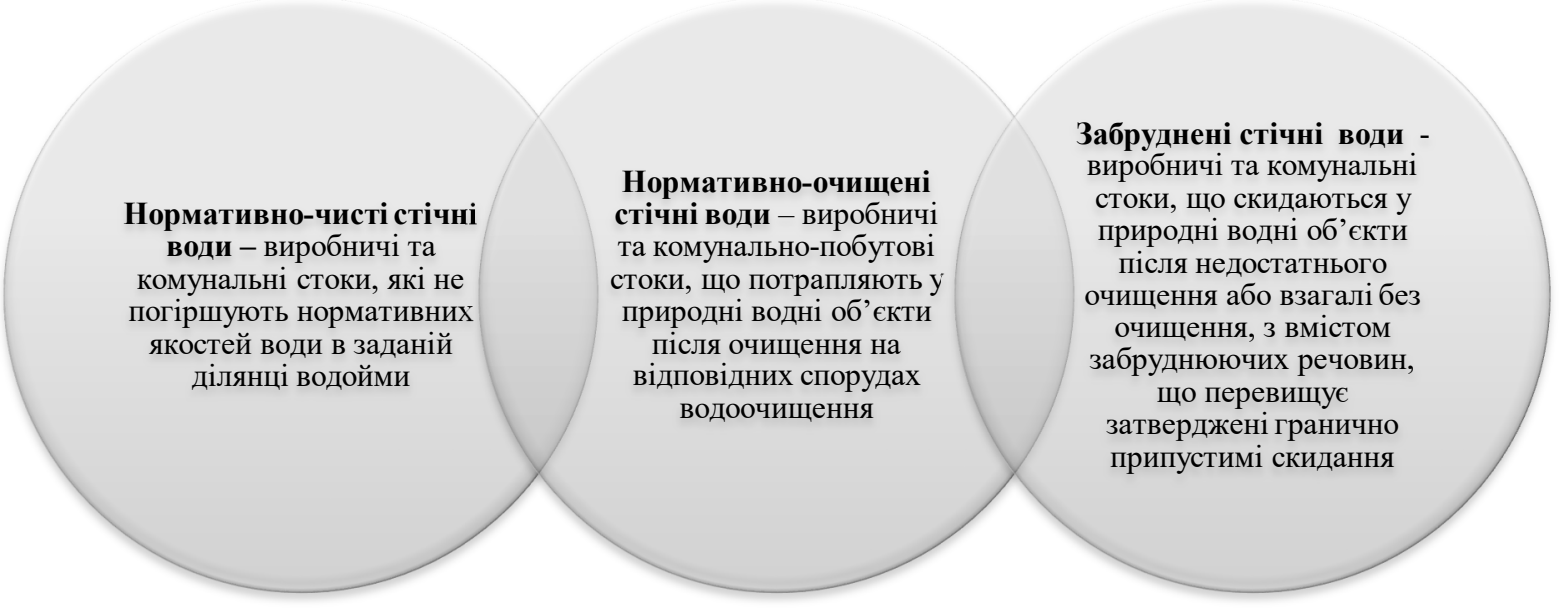

Рис. 7. Класифікація категорій стічних вод за категоріями якості скинутої води Джерело: складено авторами за [4].

Скиди стічних вод у Чернігівській області за категоріями якості розподілились таким чином (табл. 3).

Таблиця 3

Обсяги та структура скидів стічних вод за категоріями якості в Чернігівській області за даними 2020 року

\begin{tabular}{|l|c|c|}
\hline \multicolumn{1}{|c|}{ Стічні води за категоріями якості } & $\begin{array}{c}\text { Обсяги скидів, } \\
\text { млн м }^{\mathbf{3}}\end{array}$ & $\begin{array}{c}\text { Питома вага, } \\
\text { \% }\end{array}$ \\
\hline Нормативно чисті & 48,38 & 72 \\
\hline Нормативно очищені, які пройшли очищення на очисних спорудах & 8,45 & 12 \\
\hline Забруднені стічні води & 10,78 & 16 \\
\hline
\end{tabular}

Джерело: складено за даними [5].

Скиди забруднених стічних вод у поверхневі водні об'єкти області становлять $16 \%$ від загального обсягу скидів, що є сигналом для термінового вжиття заходів для можливого зменшення цього показника. Це потребує зважених та конструктивних дій стосовно вивчення можливостей очищення стічних вод.

Недостатня ефективність роботи водоочисних споруд не лише спричиняє погіршення якості води, а й несе загрозу для здоров'я людей, спричиняє захворюваність кишковими інфекціями, гепатитами, збільшує ризик дії на організм людини канцерогенних і мутагенних чинників.

Останнім часом спостерігається збільшення надходження сполук фосфатів у водойми Чернігівської області кількості. Порівняно з 2015 роком цей показник зріс із 96,8 тонни фосфатів до 106,7 тонни у 2020 році [5].

Комунальні стоки із залишками пральних порошків виступають основним джерелом забруднення водойм фосфатами, від добрив у воду надходить 10-30 \% фосфору. Фосфати, потрапляючи у водойми, зумовлюють неконтрольоване зростання водоростей. Вода набуває зеленого кольору та стає непридатною для використання людиною. У результаті відмирання водоростей у водоймах відбуваються процеси гниття. Бактерії, які окислюють органічні сполуки, активно споживають розчинений у воді кисень, а це спричиняє кисневе голодування. Риба та все живе у водоймах гине.

Високий вміст фосфатів кардинально змінює процес очищення річкової води. Необхідна кількість реагентів та витрат електроенергії для процесу очищення зростає в рази. При очищенні стічних вод відбувається погіршення якості очищення стоків у результаті загибелі бактерій активного мулу, які перероблюють стоки на чисту воду. 
ТЕОРЕТИЧНІ ПРОБЛЕМИ РОЗВИТКУ НАЦІОНАЛЬНОЇ ЕКОНОМІКИ

При недостатньому очищенні води фосфати потрапляють в організм людини, що спричиняє знежирення шкірного покрову, може викликати прояви алергічних реакцій.

Наслідки впливу забруднення на організм людини важко не помітити. Серйозною проблемою $є$ захворювання, викликані забрудненням навколишнього середовища. Вони викликають зростання онкологічних захворювань, призводять до алергічних реакцій. Якість питної води є запорукою довголіття, а тому необхідно приділяти велику увагу екології та технологіям очищення питної води. Експертами ВООЗ з'ясовано, що майже 80 \% інфекційних захворювань у світі спричинені вживанням неякісної питної води та недотриманням санітарно-гігієнічних норм водопостачання.

Вживання неякісної питної води викликає у 25 \% населення збільшення захворювань серцево-судинної системи, шлунково-кишкового тракту, ендокринних та алергічних захворювань, новоутворень, водно-нітратної метгемоглобінемії, флюорози, отруєння токсинами синьо-зелених водоростей тощо.

У міжнародній практиці офіційне визнання отримав термін «захворювання, пов'язане 3 навколишнім середовищем» (environmental disease), який позначає будь-яке захворювання, що виникає безпосередньо або опосередковано, повністю або частково в результаті впливу факторів навколишнього середовища на людину. Поряд зі специфічними захворюваннями, викликаними впливом того чи іншого фактору навколишнього середовища, існує надзвичайно велика кількість захворювань і синдромів, що не мають безпосереднього етіологічного зв'язку з впливом, але фактори навколишнього середовища або збільшують ризик розвитку добре вивчених і поширених хвороб (наприклад, серцевосудинних захворювань), або модифікують їх клінічний перебіг, або виступають у ролі тригерів, що викликають прискорення реалізації вже наявних у людини патологічних станів (передчасна смерть, напад бронхіальної астми, скорочення тривалості або зниження якості життя). Погіршення стану здоров'я зумовлює збільшення витрат на лікування як на рівні держави, територіальних громад, так і на рівні особистості [6].

Оскільки тривалість та якість життя людини залежить від наявності та стану водних ресурсів, то забезпечення населення та галузей національної економіки якісною водою $\epsilon$ пріоритетним завданням соціально-економічної політики держави. Раціональне використання водних ресурсів є невід'ємною складовою природокористування, яке віддзеркалює найбільш економічно та соціально та екологічно зорієнтовану форму взаємозв'язку людини з довкіллям та є умовою збереження іiі життєдіяльності [9, с. 36].

Експерти Bloomberg, які досліджували 169 держав за рівнем здоров'я населення встановили, що першу трійку сформували Іспанія, Італія та Ісландія. Україна у цьому рейтингу на 93-му місці. При формуванні рейтингу експерти враховували тривалість життя, якість та доступність питної води, клімат та інші фактори [16].

У світових рейтингах якості питної води Україна займає низькі рейтингові позиції (116-е місце). 3 кожним роком збільшується ймовірність недостатнього забезпечення потреб населення і галузей національної економіки у водних ресурсах, неналежного збереження водних ресурсів та їх відтворення. Ситуація в окремих регіонах країни є дуже тривожною.

За кількістю питної води в розрахунку на душу населення Україна перебуває на 125-му місці зі 180 країн. Крім того, на основі даних Центрів з контролю і профілактики захворювань Міністерства охорони здоров'я США, Україна входить до країн з найбільш небезпечною і несмачною водопровідною водою. Оцінки Всесвітнього фонду природи свідчать про те, що Україна не докладає належних зусиль для вирішення проблем дефіциту та зниження якості прісної води.

Майже на третині території країни (27\%) можливі негативні наслідки повеней та паводків, які $є$ причиною $70 \%$ усіх смертей у результаті стихійних лих [1]. В Україні погіршується стан водних об’єктів. 
Якість води в багатьох регіонах України не відповідає вимогам стандарту на питну воду. Це викликане не лише природними умовами, а й антропогенним забрудненням, недостатнім очищенням стічних вод. В артезіанських водах проявляється підвищений вміст заліза, марганцю, солей, хлоридів, сульфатів, фтору, нітратів тощо [11].

Для покращення екологічних показників водних ресурсів України першопочатково необхідно вирішити такі завдання, як:

- зменшити рівень забруднення стічних вод шляхом реконструкції і ремонту каналізаційних мереж і споруд;

- розробити та використовувати в освітніх програмах навчальних курсів навчальних закладів усіх рівнів Концепцію формування екологічних потреб, що може суттєво зменшити рівень забруднення через зменшення використання побутової хімії населенням;

- за допомогою фінансових, адміністративних важелів на державному рівні сприяти формуванню соціальної відповідальності бізнесу та екологічної свідомості.

Екологічні потреби особистості проявляються в необхідності мінімізації забруднення навколишнього середовища, сприянні безвідходності виробництва та використанні тих природних ресурсів, які можуть відтворюватись. Завданням держави при цьому є:

- формування екологічного світогляду в усіх членів суспільства, високої екологічної культури, запобігання безвідповідальному ставленню до природи;

- зменшення забруднення навколишнього середовища за рахунок дбайливого ставлення до природних ресурсів.

Збереження необхідних умов для природного середовища повинно опиратися на формування в довгостроковому плані системи екологічних потреб з врахуванням необхідних стандартів життєзабезпечення та можливістю задоволення як економічних, так і екологічних потреб майбутніх поколінь. Виконання такого стратегічного завдання, як формування екологічних потреб покладене на Міністерство освіти та науки України, освітні інститути всіх рівнів, особливо дошкільні та загальноосвітні заклади. Важливе значення при цьому належить інституту сім'ї.

У процесі державного регулювання при стабілізації екологічної ситуації та покращення якості навколишнього середовища пріоритети задоволення особистих потреб мають зміщуватись у напрямку екологізації потреб, проявлятись потреби майбутніх поколінь тощо. Екологізація потреб має сприяти самовідновлювальній здатності природи. Темпи, структура і культура споживання мають формуватись відповідно до екологічних обмежень. Напрямом зменшення навантаження на екосистему є збалансоване споживання, благополуччя населення нині без збитку для майбутніх поколінь[15].

Одним із пріоритетів впливу держави на потреби особистості в частині екологізації доцільно створення відповідної законодавчої бази, зокрема, закріплення в конкретних законодавчих актах заборони на несанкціоновані викиди відходів, підвищення штрафів за скид забрудненої води у природне середовище тощо [7, с. 117-118].

Неможливість виконання державою всіх еколого-економічних функцій тільки підвищує актуальність реалізації бізнесом соціальних функцій у розрізі соціальної відповідальності бізнесу. Добровільне інвестування частини прибутку в очисні споруди, зменшення обсягів забруднених стічних вод, використання замкнутих циклів водокористування сприяють досягненню у довгостроковій перспективі соціального чи економічного ефекту (покращення стану здоров'я населення, збільшення пропозиції на ринку праці, мінімізація витрат на лікарняні листи тощо).

Висновки і пропозиції. Результати проведеного дослідження підтверджують, що в Україні найнижчий серед європейських країн показник здорового життя, зумовлений не тільки рівнем, способом життя населення, генетичними чинниками, доступністю медичних послуг, але і значною мірою - якістю водних ресурсів. Оскільки тривалість та якість життя 
ТЕОРЕТИЧНІ ПРОБЛЕМИ РОЗВИТКУ НАЦІОНАЛЬНОЇ ЕКОНОМІКИ

людини залежить від наявності та стану водних ресурсів, то забезпечення населення та галузей національної економіки якісною водою $є$ пріоритетним завданням соціальноекономічної політики держави. Для покращення екологічних показників водних ресурсів України необхідно вирішити такі завдання: зменшити рівень забруднення стічних вод шляхом реконструкції і ремонту каналізаційних мереж і споруд, використання сучасних технологій очищення води; сприяти на державному рівні формуванню екологічних потреб, що може суттєво зменшити рівень забруднення; створювати програми стимулювання соціальної відповідальності бізнесу за допомогою фінансових, адміністративних важелів.

\section{Список використаних джерел}

1. В Україні погіршується стан водних об'єктів, якість питної води та водна інфраструктура / Рахункова палата. 2021. URL: https://rp.gov.ua/PressCenter/News/?id=1126.

2. Дерій Ж. В., Вінниченко К. О. Інструменти екологічної політики при вирішенні проблем раціонального використання земельних ресурсів. Проблеми і перспективи економіки та управління. 2018. № 4 (16). С. 7-15.

3. Дослідження антропогенного впливу на гідрологічний та екологічний режим р. Остер Чернігівської області: звіт про науково-дослідну роботу / Ж. В. Дерій, Н. Т. ШадураНикипорець, С. Д. Цибуля, О. Ю. Купчик. Чернігів, 2017. 255 с.

4. Івашко В. Г., Ольвінська Ю. О. Статистичний аналіз стану та використання водних ресурсів України. Статистика - інструмент соиіально-економічних досліджень : збірник наукових студентських праць. 2017. Випуск 3. Частина I. С. 82-89.

5. Інформація про використання водних ресурсів Чернігівської області у 2020 році. Деснянське басейнове управління водних ресурсів. URL.: https://desna-buvr.gov.ua/diyalnist/.

6. Кичко I. I. Макроекономічний механізм фінансування охорони здоров'я. Фінанси Украйни. 2003. № 4. С. 71-77.

7. Кичко I. I. Соціально-економічні детермінанти особистих потреб. Чернігів : Чернігівський державний технологічний університет, 2013. 333 с.

8. Кичко I. І., Холодницька А. В. Мотиваційний імператив реалізації управлінських компетенцій та збалансування ринку праці в Україні. Проблеми і перспективи економіки та управління. 2021. № 1 (25). С. 7-14.

9. Климчик О. М., Пінкіна Т. В., Пінкін А. А. Впровадження системи інтегрованого управління водними ресурсами за басейновим принципом. Scientific Journal «ScienceRise». 2018. № 4 (45). С. 36-40.

10. Левковська Л. В., Мандзик В. М. Формування моделі інтегрованого управління водними ресурсами в контексті забезпечення сталого водокористування. Збалансоване природокористування. 2018. № 2. C. 46-53. URL: http://nbuv.gov.ua/UJRN/Zp_2018_2_9.

11. Лотоцька О. В., Кондратюк В. А., Кучер С. В.. Якість питної води як одна з детермінант громадського здоров'я в західному регіоні України. Вісник сочіальної гігієни та організачії охорони здоров'я України. 2019. № 1 (79). С. 12-18.

12. Мандзик В. М. Капіталізація водних ресурсів: теорія і практика. Київ : ПрофКнига, 2018. $287 \mathrm{c}$.

13. Мишенин Е. Концептуальные основы функционирования экологически ориентированного механизма управления природохозяйствованием. Экономист. 2012. № 5. С. 59-61.

14. Мовчан С. І. Вплив екологічних показників на якість життя населення. Наука, освіта, суспільство: реалії, виклики, перспективи : зб. матеріалів конференції. Вінниця: ТОВ «ТВОРИ», 2019. T. 1. C. $155-157$.

15. Наше будущее: доклад Международной комиссии по окружающей среде и развитию (МКОСР) / под ред. и с послесл. С. А. Евтеева и Р. А. Перелета. Москва : Прогресс, 1989. 376 с.

16. Стадник В. 10 найздоровіших країн у світі - Bloomberg. 2020. URL: https://www.thevillage.com.ua/village/city/city-news/282343-10-nayzdorovishih-krayin-u-sviti-bloomberg.

17. Холодницька А.В. Індикативне оцінювання якості життя населення Чернігівської області. Проблеми і перспективи економіки та управління. 2015. № 4. С. 93-100. 
18. Шаріпов О. У 2019 році в Україні була найнижча серед європейських країн тривалість здорового життя - дослідження. URL: https://hromadske.ua/posts/u-2019-roci-v-ukrayini-bulanajnizhcha-sered-yevropejskih-krayin-trivalist-zdorovogo-zhittya-doslidzhennya.

19. World Health Organization. The Global Health Observatory. URL.: https://www.who.int/data/ gho/data/themes/mortality-and-global-health-estimates.

20. Human Development Report 2020. URL: http:/hdr.undp.org/sites/default/files/hdr2020.pdf.

\section{References}

1. Rakhunkova palata [Accounting Chamber]. (2021). V Ukraini pohirshuietsia stan vodnykh obiektiv, yakist pytnoi vody ta vodna infrastruktura [In Ukraine, the condition of water bodies, drinking water quality and water infrastructure is deteriorating]. https://rp.gov.ua/PressCenter/News/?id=1126.

2. Derii, Zh.V., \& Vinnychenko, K.O. (2018). Instrumenty ekolohichnoi polityky pry vyrishenni problem ratsionalnoho vykorystannia zemelnykh resursiv [Tools of ecological policy at the decision of problems of rational use of land resources]. Problemy i perspektyvy ekonomiky ta upravlinnia Problems and prospects of economics and management, (4(16)), 7-15.

3. Derii, Zh.V., Shadura-Nykyporets, N.T., Tsybulia, S.D., \& Kupchyk, O.Yu. (2017). Doslidzhennia antropohennoho vplyvu na hidrolohichnyi ta ekolohichnyi rezhym $r$. Oster Chernihivskoi oblasti: zvit pro naukovo-doslidnu robotu [Research of anthropogenic impact on the hydrological and ecological regime of the Oster River, Chernihiv region: report on research work].

4. Ivashko, V.H., \& Olvinska, Yu.O. (2017). Statystychnyi analiz stanu ta vykorystannia vodnykh resursiv Ukrainy [Statistical analysis of the state and use of water resources of Ukraine]. Statystyka instrument sotsialno-ekonomichnykh doslidzhen: zbirnyk naukovykh studentskykh prats - Statistics - a tool of socio-economic research: a collection of scientific student papers, 3(I), 82-89.

5. Desnianske baseinove upravlinnia vodnykh resursiv [Desnyansk basin management of water resources]. (2020). Informatsiia pro vykorystannia vodnykh resursiv Chernihivskoi oblasti u 2020 rotsi [Information on the use of water resources of Chernihiv region in 2020]. https://desnabuvr.gov.ua/diyalnist.

6. Kychko, I.I. (2003). Makroekonomichnyi mekhanizm finansuvannia okhorony zdorovia [Macroeconomic mechanism of health care financing]. Finansy Ukrainy - Finance of Ukraine, 4, 71-77.

7. Kychko I. I. (2013). Sotsialno-ekonomichni determinanty osobystykh potreb [Socio-economic determinants of personal needs]. Chernihivskyi derzhavnyi tekhnolohichnyi universytet.

8. Kychko, I.I., \& Kholodnytska, A.V. (2021). Motyvatsiinyi imperatyv realizatsii upravlinskykh kompetentsii ta zbalansuvannia rynku pratsi v Ukraini [Motivate smperative for implementing management competencies and balancsng the labor market]. Problemy i perspektyvy ekonomiky ta upravlinnia - Problems and prospects of economics and management, (1(25)), 7-14.

9. Klymchyk, O.M., Pinkina, T.V., \& Pinkin, A.A. (2018). Vprovadzhennia systemy intehrovanoho upravlinnia vodnymy resursamy za baseinovym pryntsypom [Introduction of an integrated water resources management system based on the basin principle]. Scientific Journal «ScienceRise», (4(45)), 36-40.

10. Levkovska, L.V., Mandzyk, V.M. (2018). Formuvannia modeli intehrovanoho upravlinnia vodnymy resursamy v konteksti zabezpechennia staloho vodokorystuvannia [Formation of a model of integrated water resources management in the context of ensuring sustainable water use]. Zbalansovane pryrodokorystuvannia - Balanced nature management, 2, 46-53.

11. Lototska, O.V., Kondratiuk, V.A., \& Kucher, S.V. (2019). Yakist pytnoi vody yak odna z determinant hromadskoho zdorovia $\mathrm{v}$ zakhidnomu rehioni Ukrainy [Quality of drinking water as one of the determinants of public health in the Western region in the Ukraine]. Visnyk sotsialnoi hihiieny ta orhanizatsii okhorony zdorovia Ukrainy - Bulletin of social hygiene and health care organization of Ukraine, 1(79), 12-18.

12. Mandzyk, V.M. (2018). Kapitalizatsiia vodnykh resursiv: teoriia i praktyka [Capitalization of water resources: theory and practice]. ProfKnyha.

13. Mishenin, E. (2012). Konceptualnye osnovy funkcionirovaniya ekologicheski orientirovannogo mekhanizma upravleniya prirodohozyajstvovaniem [Conceptual bases of functioning of the ecologically oriented mechanism of management of nature management]. Ekonomist Economist, (5), 59-61. 
ТЕОРЕТИЧНІ ПРОБЛЕМИ РОЗВИТКУ НАЦІОНАЛЬНОЇ ЕКОНОМІКИ

14. Movchan, S.I. (2019). Vplyv ekolohichnykh pokaznykiv na yakist zhyttia naselennia [Influence of ecological indicators on quality of living of the population]. Nauka, osvita, suspilstvo: realii, vyklyky, perspektyvy - Science, education, society: realities, challenges, prospects (vol. 1, pp. 155-157). TOV «TVORY».

15. Evteeva, S.A., Pereleta, R.A. (Eds.). (1989). Nashe budushchee: doklad Mezhdunarodnoi komissii po okruzhaiushchei srede i razvitiu (MKOSR) [Our future: report of the International Commission on Environment and Development (ICSD)]. Progress.

16. Stadnyk, V. (2020). 10 naizdorovishykh krain u sviti - Bloomberg. 2020. https://www.thevillage.com.ua/village/city/city-news/282343-10-nayzdorovishih-krayin-u-sviti-bloomberg.

17. Kholodnytska, A.V. (2015). Indykatyvne otsiniuvannia yakosti zhyttia naselennia Chernihivskoi oblasti [Indicative assessment of the quality of life of the population of Chernihiv region]. Problemy i perspektyvy ekonomiky ta upravlinnia - Problems and prospects of economics and management, (4), 93-100.

18. Sharipov, O. (2020). U 2019 rotsi v Ukraini bula nainyzhcha sered yevropeiskykh krain tryvalist zdorovoho zhyttia - doslidzhennia [Ukraine had the lowest life expectancy among European countries - a study]. https://hromadske.ua/posts/u-2019-roci-v-ukrayini-bula-najnizhcha-seredyevropejskih-krayin-trivalist-zdorovogo-zhittya-doslidzhennya.

19. World Health Organization. The Global Health Observatory. https://www.who.int/data/gho/ data/themes/mortality-and-global-health-estimates.

20. Human Development Report 2020. (2020). http://hdr.undp.org/sites/default/files/hdr2020.pdf.

Кичко Ірина Іванівна - доктор економічних наук, професор, професор кафедри управління персоналом та економіки праці, Національний університет «Чернігівська політехніка» (вул. Шевченка, 95, м. Чернігів, 14035, Україна).

Kychko Iryna - Doctor of Economic Sciences, Professor, Professor of Department of Personnel Management and Labour Economy, Chernihiv Polytechnic National University (95 Shevchenka Str., 14035 Chernihiv, Ukraine).

E-mail: ira41215@ukr.net

ORCID: https://orcid.org/0000-0002-1110-4177

ResearcherID: H-1753-2015

Холодницька Алла Вячеславівна - кандидат економічних наук, доцент, доцент кафедри управління персоналом та економіки праці, Національний університет «Чернігівська політехніка» (вул. Шевченка, 95, м. Чернігів, 14035, Україна).

Kholodnytska Alla - PhD in Economics, Associate Professor, Associate Professor of the Department of Personnel

Management and Labour Economics, Chernihiv Polytechnic National University (95 Shevchenka Str., 14035

Chernihiv, Ukraine).

E-mail: allakholodnytska@ukr.net.

ORCID: https://orcid.org/0000-0001-5563-3591

ResearcherID: G-9430-2014

Кичко І., Холодницька А. Раціональне водокористування в контексті забезпечення населення якісною питною водою, збереження здоров'я та тривалості життя. Проблеми і перспективи економіки та управління. 2021. № 2(26). С. 7-17. 